\title{
AGENTS FOR DEFENSE AGAINST CHEMICAL WARFARE: REACTIVATORS OF ACETYLCHOLINESTERASE INHIBITED WITH NEUROTOXIC ORGANOPHOSPHORUS COMPOUNDS**
}

\author{
Petronilho, E. C., Figueroa-Villar, J. D. ${ }^{\circledR}$ \\ Chemistry Engineering Section, Medicinal Chemistry Group, Military Institute of Engineering, Praça General \\ Tibúrcio, 80, Urca, 22290-270, Rio de Janeiro, RJ, Brazil.
}

Received 30 $0^{\text {th }}$ April 2015.

Revised $7^{\text {th }}$ July 2015.

Published $4^{\text {th }}$ September 2015.

\begin{abstract}
Summary
The chemical warfare agents and neurotoxic agents are an important threat to people all over the world, and require special attention because they are highly dangerous. Most of these agents are neurotoxic organophosphorus compounds (OP), which inhibit the enzyme acetylcholinesterase (AChE), which is responsible for controlling the transmission of nerve impulses. To be inhibited by these compounds, AChE can sometimes be reactivated using cationic oximes, which are the most used substances for this reactivation. Until today there have not been discovered agents for complete treatment of poisoning by all OPs. For this reason, the treatment of intoxicated people requires the determination of the absorbed OP, in order to select the appropriate activator, a process that usually requires long time and may cause death. Therefore, this study aims to do a review on the OPs used as chemical warfare agents and the process of inhibition and reactivation of $\mathrm{AChE}$, especially to motivate the development of new agents for defense against chemical weapons, a process that is very important for protecting all humanity.
\end{abstract}

Key words: acetylcholinesterase; AChE reactivators; organophosphorus; oximes; warfare agents

\section{INTRODUCTION}

The use of chemical warfare agents is a major threat in the world today. The chemical warfare is based on the use of substances with toxic properties, which are capable of killing, for mass destruction, and causing severe damage to the environment [1]. The most prominent and dangerous chemical warfare agents are neurotoxic organophosphorus com-

X Military Institute of Engineering, Department of Chemistry, Praça General Tibúrcio 80, CEP 22280-270, Urca, Rio de Janeiro, RJ, Brazil.

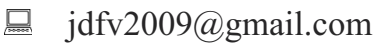

pounds (OP), which are highly toxic, allowing their use with small quantities in order to cause seizures and death.

One of the biggest reasons for the use of chemical warfare agents in war and terrorist actions is that their use affords minimal cost compared with the conventional weapons, such as bombs, missiles and explosives. For example, to kill all the people present in one region from a square kilometer area, the use of chemical weapons usually affords one cost of approximately $40 \%$ lower from normal weapons [2]. The other reason is that these chemical weapons, besides causing death quickly and efficiently, also cause psychological problems to some people that survive

** This manuscript was transferred to English from the manuscript: "Agentes para Defesa Contra Guerra Química: Reativadores da Acetilcolinesterase Inibida com Organofosforados Neurotóxicos" published in the "Revista Virtual de Química", 2014, 6 (3), 671-686. DOI: http://dx.doi.org/10.5935/1984-6835.20140042. 
from this poisoning, with more concern than other weapons.

Chemical warfare agents were used several times in wars since antiquity, but some of these agents were not well defined and none very efficient. Several more efficient toxic agents received greater importance in 1915, when the German army launched gases, such as chlorine and mustard against French troops during the First World War, causing numerous casualties in the enemy army [2]. Afterwards the development of nerve agents was more intense for many armies. Before the Second World War the German army started the development of the first OP neurotoxic as chemical warfare agents, especially tabun (GA), sarin ( GB) and soman (GD) (Figure 1). Nevertheless, these agents as well as mustard gas and other toxic substances, were not used during World War II. During the 1950s, the neurotoxic OP V family was developed, being one of the more toxic and persistent in the environment, named VX, which was developed in England. After this time there were created similar compounds, especially in the former Soviet Union (Figure 1) [2].
One of the first countries that used neurotoxic OPs was Iraq, under the command of Saddam Hussein in the war against Iran, between 1980 and 1988, leading to hundreds of Iranians deaths [4]. In 1988, Hussein also used the nerve agent tabun against Kurds, causing many other deaths [5].

In 1994, sarin was used in Japan against civilians in a terrorist attack that killed 7 and poisoned 200 people [6]. The following year there was another attack in Japan by the same terrorist group using sarin, being on a subway station in Tokyo, causing the poisoning of 5.000 victims and the death of 12 people $[7,8,9]$. In the following years, many of the intoxicated people also died or were in poor health.

On the other hand, there was poisoning of American soldiers by sarin during the Gulf War in 1991, possibly when these soldiers destroyed a deposit of chemical weapons in Iraq. In 2003, the United States, with the England support, invaded Iraq because the country had deposits of chemical weapons at the time $[8,9]$. In 2004 one sarin gas grenade exploded in Baghdad, after being discovered by coalition troops, leaving two injured $[8,9]$.<smiles>CC(C)OP(C)(=O)F</smiles>

Sarin<smiles>CCOP(C)(=O)SCCN(C(C)C)C(C)C</smiles>

VX<smiles>COP(=O)(OC)c1ccc([N+](=O)[O-])cc1</smiles>

Paraoxon<smiles>CS(=O)(O)(F)OC1CCCCC1</smiles>

Cyclosarin<smiles>CC(C)COP(C)(=O)SCCN(C(C)C)C(C)C</smiles>

Russian VX<smiles>CC(Cl)C(C)OP(=O)(F)O/N=C(\F)Cl</smiles>

Novichok 5<smiles>CC(OP(C)(=O)F)C(C)(C)C</smiles>

Soman<smiles>COP(C)(=O)OC</smiles><smiles>CCOP(C)(=O)SCCN(CC)CC</smiles>

Edemo (VM)

Figure 1. Structure example of some neurotoxic organophosphorus agents [3]. 
Recently, chemical weapons were used in Syria, leading to the death of about 1300 people, especially civilians and children, this act being one of the worst events in use of chemical weapons in the world. These cases show that the use of chemical weapons remains as a major threat to the security of any country. Fortunately, there exists the Organization of the Prohibition of Chemical Weapons (OPCW) of ONU, which prohibits their development, production, storage and use. This convention also promotes the elimination of existing stockpiles of such weapons [10].

Unfortunately, some countries still do not participate in OPCW and terrorist groups can easily use chemical weapons. The low cost and simple manufacture of chemical weapons induce the interest from terrorist organizations, which is a major worldwide concern [11].

Another important aspect with respect to OP is its use as pesticides in agriculture [12]. For example, the ONU has reported that about two million people every year try to commit suicide with OP pesticides or insecticides, and about a million people are poisoned with these compounds accidentally $[13,14]$. A recent example of this problem was the poisoning of 50 children in a school in India with OP in 2013, leaving 23 dead, including several more who were hospitalized $[15,16]$. Unfortunately, these pesticides and insecticides have been used worldwide for assassination and suicides [17]. These pesticides are often contaminating agricultural products, such as fruits and other vegetables, that when eaten without being cleaned, can lead to toxicity with the possibility of death or cholinergic actions.

The OPs normally act as inhibitors of the enzyme acetylcholinesterase (AChE), which is fundamental to our nerve transmission control system. Currently, there is not one drug able to reactivate this enzyme if it is inhibited by any neurotoxic OP. For this reason, in the first treatment action, it is usually necessary to determine the used OP compound for intoxication of one person, in order to select the best drug for reactivation treatment. Unfortunately, this determination usually requires a long time, preventing the low treatment of the intoxicated person, which may cause his death.

For these reasons it is very important to develop new drugs to save the lives of people poisoned by OP, to develop new substances that are able to efficiently reactivate $\mathrm{AChE}$ independent of which OP was used for poisoning.

\section{Organophosphates}

The most used OPs as intoxicants or pesticides are derived from phosphoric, phosphonic, phosphinic or phosphoramidic acids. They have one pentavalent phosphor as central atom, which is connected in different functional groups. In general terms this central phosphor atom contains a double bond with oxygen or sulfur, but the other three single bonds can be varied. In addition, the phosphor atom is at least connected to one alkyloxyl group (RO) in all OPs, and when the other two single bonds are with RO the compounds, they are called phosphates (1). When one of RO groups is replaced by a nitrogen group $\left(\mathrm{R}_{2} \mathrm{~N}\right)$, the compounds are named phosphoramidates (2). If two simple bonds are with RO and the third is an alkyl group (R), the compounds are called phosphonates (3). It is still possible that two single bonds are with alkyl groups (R), being them named as phosphinates (4). When the double bond is with a sulfur atom, the compounds become phosphorothioates (5), phosphonothioates (6) and

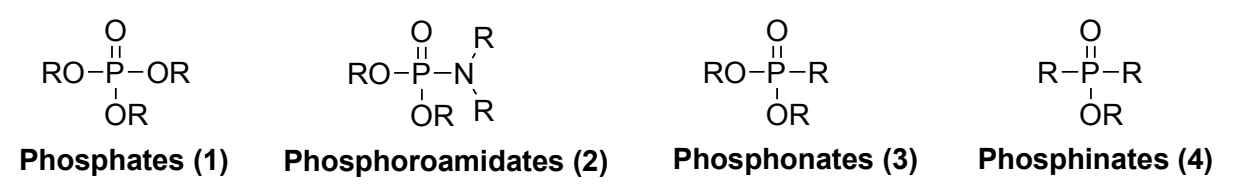

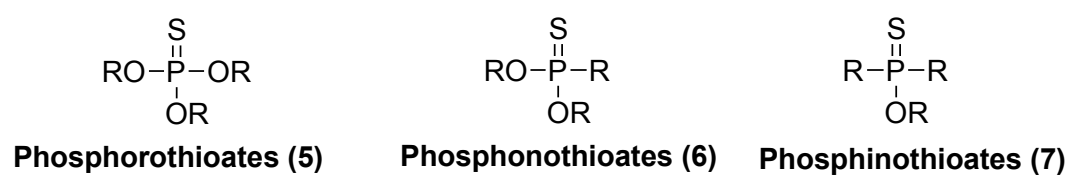

Figure 2. Example of organophosphorus compounds. 
phosphinothioates (7) (Figure 2). In OP the alkyloxyl groups $(\mathrm{RO})$ or alkyl (R) can also be aryloxyl (ArO) or aryl $(\mathrm{Ar})[18,19]$.

The scientist Jean Louis Lassaigne did one of the first jobs on the preparation of organophosphorus compounds, in France, which in the early nineteenth century produced one triethyl phosphate and studied its toxicity, motivating the search of these types of compounds. Another French scientist, Philippe de Clermont, developed the first organophosphate acetylcholinesterase inhibitor, named as tetraethyl pyrophosphate (TEEP) (8) (Figure 3). The German scientists Willy Lange described the effect of this type of compounds in the central nervous system, and Gerde von Krueger in 1932 described a process what motivated the German scientist Gerhard Schrader to prepare another OP as potential insecticides.<smiles>CCOP(=O)(OCC)OP(=O)(OCC)OCC</smiles>

(8)

Figure 3. First synthesized organophosphate insecticide (TEEP).

Several of these compounds prepared by Schrader were eventually determined as very toxic, being considered to be used as chemicals weapons [3]. These compounds were synthesized by relatively simple methods, for example, the reaction of difluoro methylphosphate (9) with isopropanol as shown in Figure 4, leading to formation of sarin (10), which was obtained with two conformations, S-(-)-sarin (10a) and R-(+)-sarin (10b).

The neurotoxic OPs used as chemical weapons are compounds which contain one alkyl and one leaving group attached to the phosphor atom. Therefore, the most toxic of these compounds, that<smiles>CC(C)OP(C)(=O)OC(C)C</smiles>

Figure 4. Synthesis of the neurotoxic organophosphate compound sarin (10a and 10b).

contain one alkyl group directly bonded to phosphorus atom, also possess leaving groups, as cyanide, fluorine and sulfur that can be easily replaced by nucleophilic groups. This structural characteristic make these compounds easily nucleophilically attackable by $\mathrm{OH}$ groups, particularly the hydroxyl group of the amino acid serine. Also other OPs pesticides and insecticides that are applied to agricultural processes and insects control have important toxicity. Despite having the intoxication of humans with OPs chemical warfare agents, the pesticides and insecticides lead to several poisonings and deaths worldwide every year. One example of toxic pesticides and insecticides is shown in Figure 5.
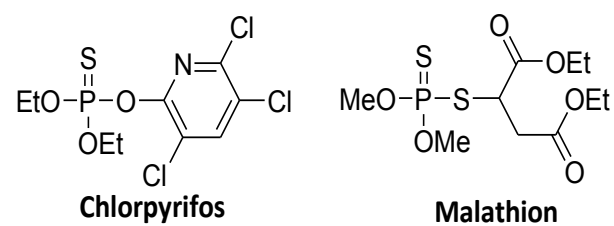

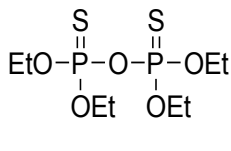

Sulfotep

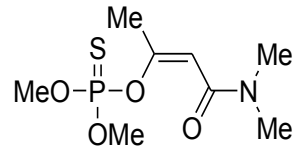

Dicrotophos

Figure 5. Example of organophosphorus pesticides and insecticides. 
The main characteristic of neurotoxic OPs is the phosphorylation of certain functional groups, especially with some amino acids from proteins, being their most common reaction with serine in the active site of cholinesterase enzymes; acetylcholinesterase (AChE) and butyrylcholinesterase (BuChE).

\section{Acetylcholinesterase (AChE)}

$\mathrm{AChE}$ is one of the most important enzymes in transmission systems of nerve impulses. A nerve impulse must always be transferred from one neuron to another, which is performed via chemical me- diators named as neurotransmitters, such as acetylcholine (ACh), enkephalin, dopamine, glutamate, norepinephrine, serotonin, and other ones. ACh is one of the most important neurotransmitters, controlling the activity of brain areas involved in care activities, learning and memory, acting on the neuromuscular junction. When this neurotransmitter is issued by a neuron into the synaptic cleft, it will interact with nicotinic and muscarinic receptors of the next neuron, transmitting the nerve impulse. To avoid excessive nerve impulse that would lead to cholinergic crisis, it is necessary that the neurotransmitter is annulled. For this reason, the enzyme $\mathrm{AChE}$ promotes to $\mathrm{ACh}$ hydrolysis, transforming this neurotransmitter to choline $(\mathrm{Ch})$ and acetate (Ac), as shown in Figure 6.
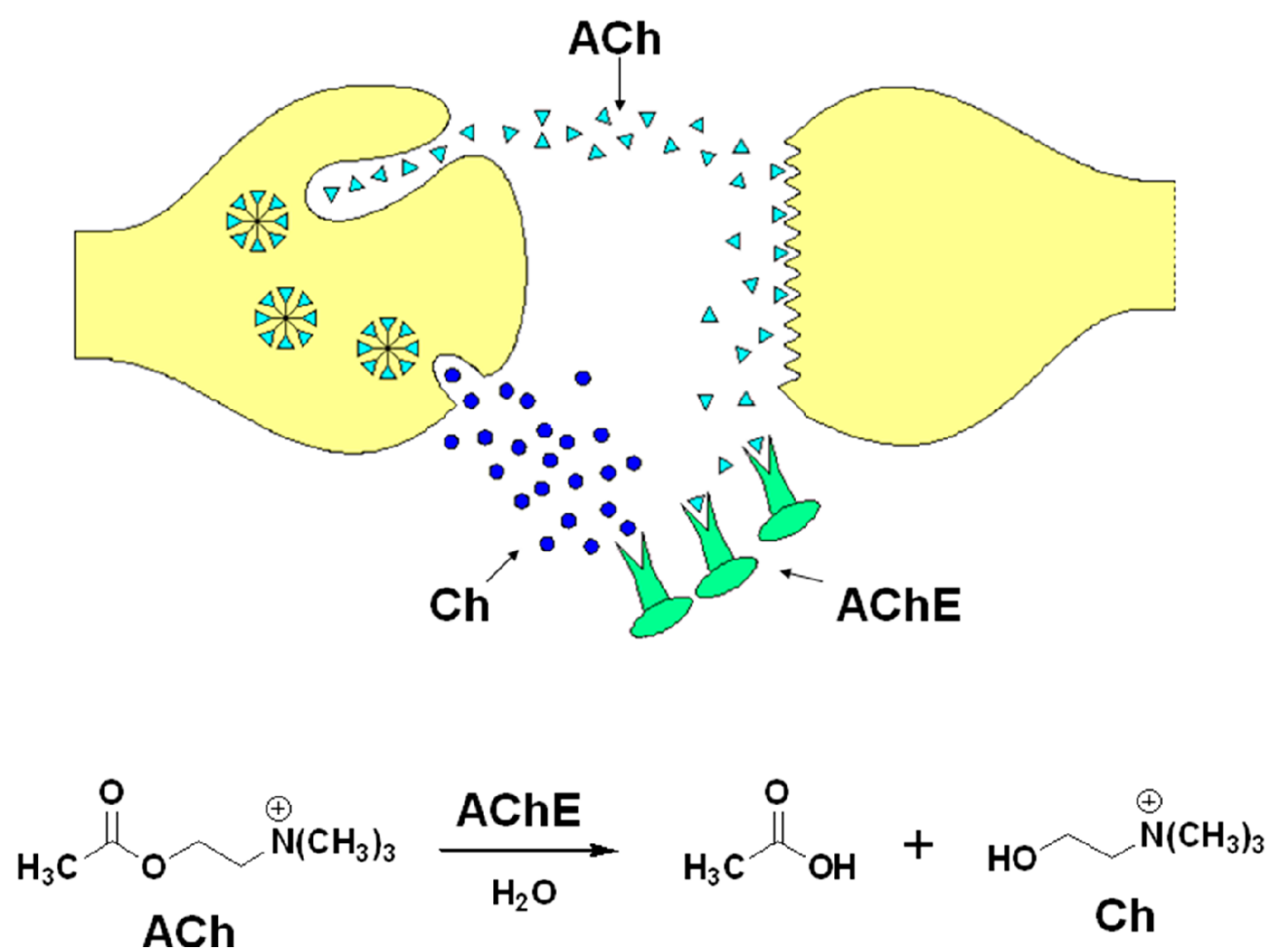

Figure 6. Neuronal transmission of acetylcholine and its hydrolysis by AChE.

As shown in Figure 6, when ACh is hydrolyzed by $\mathrm{AChE}$, the liberated choline is reabsorbed by the first neuron in order to use it for ACh formation. The principal amino acid residue from the active site of $\mathrm{AChE}$, which is involved in hydrolysis process of $\mathrm{ACh}$, is serine $\left(\mathrm{Ser}_{203}\right)$, whose action is aided by the amino acids histidine $\left(\mathrm{His}_{447}\right)$ and glutamic acid $\left(\mathrm{Glu}_{334}\right)$, as shown in Figure 7 [19].
As previously mentioned, the neurotoxic OPs inhibit the action of various enzymes, mainly AChE [3]. Inhibition of $\mathrm{AChE}$ leads to a large increase concentration of $\mathrm{ACh}$, leading to excessive nerve impulses and a cholinergic crisis, with convulsions, collapse central nervous system with loss of muscle control and severe breathing problems. These effects can lead to death relatively quickly. 


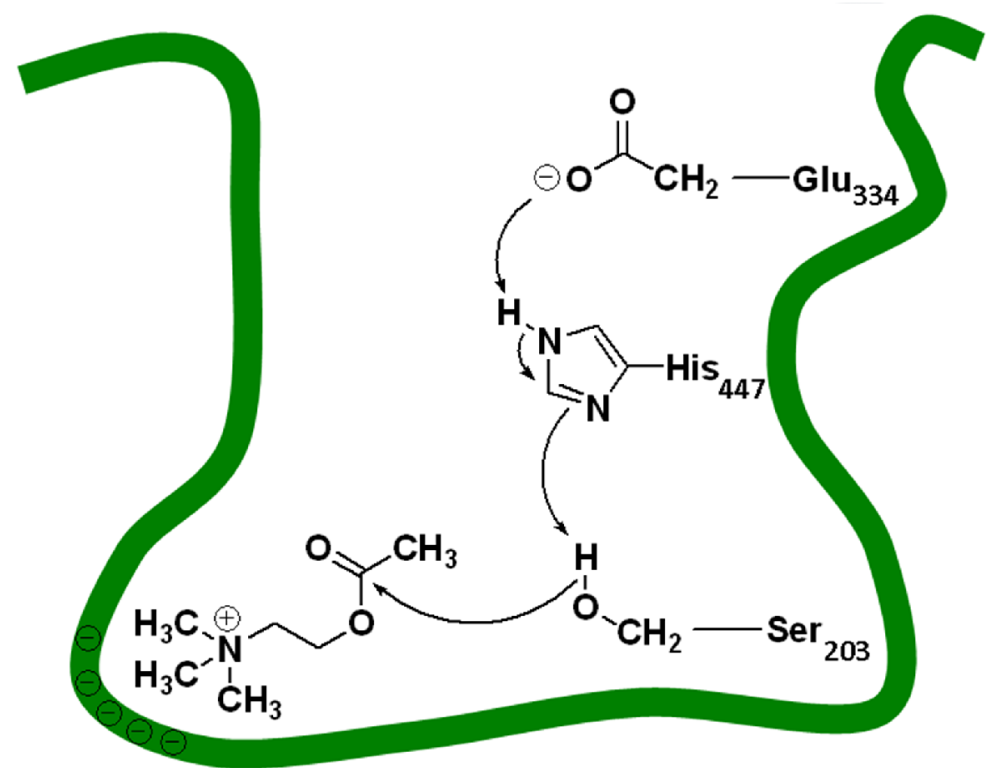

Figure 7. Hydrolysis mechanism of ACh in the active site of human AChE.

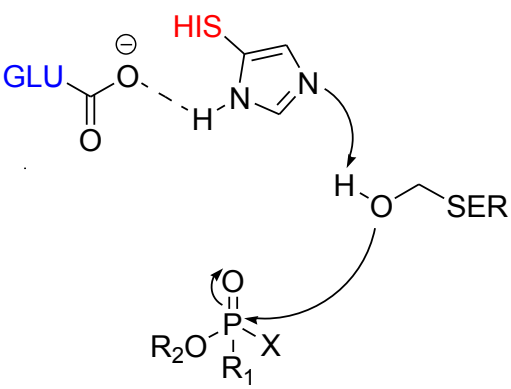

Organophosphate<smiles>O=C(Cl)COC(=O)n1c[nH+]cc1S</smiles>

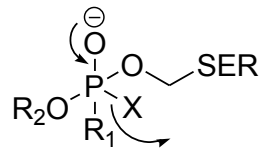<smiles>O=C(Cl)OC(=O)OCC1CCCCC1</smiles>

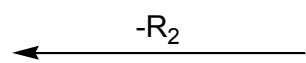

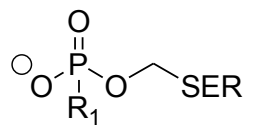

Aged enzyme<smiles>[R]OP([R])(=O)OC[SH]=[R]</smiles>

Enzyme inhibited

Figure 8. General scheme of AChE inhibition, where $\mathrm{X}$ is the leaving group of the organophosphates compounds [18]. 
The inhibition of AChE by neurotoxic OPs occurs in the central and peripheral nervous system. The organophosphorus compounds have an affinity with the AChE active site, and when the phosphorylation reaction occurred, the enzyme is inhibited without capacity to perform ACh hydrolysis. This inhibition occurs within the AChE active site, by phosphorylation of the amino acid serine of the catalytic triad $\left(\mathrm{Ser}_{203}\right)$. In the case of human AChE (HuAChE), the OPs agent binds covalently with $\mathrm{Ser}_{203}$, being this connection of the phosphorus atom with the hydroxyl group of serine, which mechanism is shown in Figure 8 [20].<smiles>CN1C(=O)CN=C(c2ccccc2)c2cc(Cl)ccc21</smiles>

Diazepam
The medical treatments for people poisoned by neurotoxic OP agents are the same principles applied to other toxic substances. For example, do not leave the victim exposed to the toxic agent, create ventilation, administer the appropriate antidotes and correct cardiac anomalies [21].

The chemotherapy action treatment for poisoning with neurotoxic organophosphorus compounds requires the use of three types of drugs. Usually, as first, diazepam is used as tranquilizer with central nervous system depressing activity. The second one is atropine, being one anticholinergic substance for

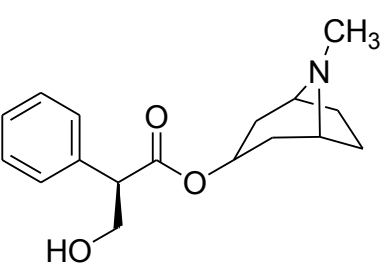

Atropine

Figure 9. Structures of atropine and diazepam used to treat poisoning caused by neurotoxic OPs [19].

antagonizing the effects of ACh accumulation in the cholinergic receptors, and a central nervous system depressant to act as anticonvulsant, and after that one oxime must be used which has the ability to reactivate the inhibited AChE [21,22]. With poisoning with OPs, atropine is the most used anticholinergic agent, which competes with the acetylcholine on the muscarinic receptor, reducing the effects caused by the excess of ACh. Among central nervous system depressants, diazepam is the most widely used (Figure 9).

\section{AChE Reactivation process}

As mentioned above, the OPs inhibit AChE by phosphorylation process (Figure 6). When this inhibition is done, the phosphorylated esterase site undergoes hydrolytic regeneration with a very slow speed. Wilson, in 1951, showed in his research that nucleophilic molecules such as oximes, hydroxylamines and hydroxamic acids could reactivate the enzyme with higher speed than the spontaneous hydrolysis. Furthermore, Wilson found that AChE, with its esterase lost capacity, could be restored by removing the phosphor group from the enzyme with some compounds. The selective reactivation of AChE could be achieved by one nucleophilic agent, which its cationic group could interact with the negative sub site of the en-zyme active center, leaving this nucleophilic agent on position close to the phosphor atom bounded to serine [23, 24]. Wilson and Ginsburg managed this process with pralidoxime (2 -PAM), which reactivates the enzyme 1 million times faster when compared with the corresponding hydroxylamine. Also certain bisquaternary oximes were tested, indicating that these compounds are also potent AChE reactivators. However, until now, there exist no oximes with satisfactory results against all organophosphorus neurotoxic agents, being the major shortcoming of this type of treatment. Actually, the most used oximes are 2-PAM (11), trimedoxime (4-TMB) (12), obidoxime (toxogonine) (13) and HI-6 (14) (Figure 10) [25-29].

The efficiency of oximes depends from the structure of the used organophosphorus compounds, being used for the reactivation of AChE if the phosphorylated enzyme is not aging. The patient treatment effectiveness depends from the immediate antidote administration after its exposure to OP, when the enzyme-OP link is not effective. 


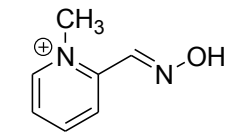

Pralidoxime (2-PAM) 11<smiles>O/N=C/c1cc[n+](COC[n+]2ccc(/C=N/O)cc2)cc1</smiles>

Obidoxime (or Toxogonine) 13<smiles>O/N=C/C1=CCN(CCC[n+]2ccc(/C=N/O)cc2)C=C1</smiles>

Trimedoxime (TMB-4) 12<smiles>NC(=O)c1cc[n+](CCC[n+]2ccc(/C=N/O)cc2)cc1</smiles>

HI-6 14

Figure 10. Mainly used oximes as antidotes for poisoning with neurotoxic organophosphorus compounds [18].

Other treatments to prevent or reduce the poisoning from OPs have also been developed. They are used when there is the exposure possibility of the neurotoxic organophosphorus agents. This treatment is a protection of $\mathrm{AChE}$, which is made by pre-contamination from carbamates that are reversible inhibitors. These compounds bind to AChE, preventing the interaction of neutoxic agent with the enzyme active site. Another treatment emerged in the late twentieth century, using enzymes (cholinesterase, phosphotriesterase or human paraoxonase) to degrade OPs at the bloodstream before occurring interaction with AChE. They are called "scavengers" [30].

Figure 11 shows the proposed mechanism for $\mathrm{AChE}$ reactivation by oximes. It is observed that the effective reactivation of this enzyme depends on the reactivator nucleophilicity. The phosphoryloxime is formed after the oxime nucleophilic attack to the phosphor atom bounded to serine [31].

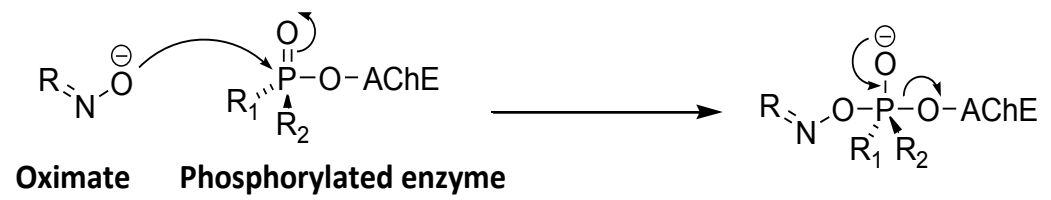<smiles>[R]NOP([R7])(=O)O[C@H](OC)[C@@H](OC)c1ccccc1</smiles>

Figure 11. Reactivation mechanism of AChE by oximes [5].

The reactivation must be performed before the enzyme aging process occurs. Aging occurs when dealkylation of the phosphate group happens, whose feature depends on the chemical structure of the inhibitor. When the enzyme is aging the possibility of reactivation by oximes is minimal, because there is a strong link between the protonated histidine residue with the enzyme catalytic site and the oxygen atom with negative charge avoids the nucleophilic attack to the phosphate group [32].
The mechanism of the reactivation process was confirmed experimentally and by molecular modeling simulations using a hybrid method involving quantum mechanics/molecular mechanics (QM/MM) [33]. This information is essential for planning new potential reactivating agents for $\mathrm{AChE}$ inhibited by OPs.

For better reactivating action of oximes it is necessary that they must be able to permeate the blood-brain barrier (BBB), leading to better treatment of brain 
disorders. Thus, neutral reactivators, which usually penetrate the BBB well, as well as cationic ones with this ability, are needed to ensure the proper treatment of this intoxication [34, 35]. This poisoning happens both with chemical weapons as with pesticides, which affects individual and military people in war, fight against terrorism and working in agriculture.

Given this need, the Brazilian Army, by the Military Institute of Engineering (IME) and the Center of Army Technology (CTEx), especially the group of Medicinal Chemistry from IME, are dedicated to develop new agents for efficient defense against chemical weapons and pesticides.

\section{Evaluation methods of $\mathrm{AChE}$ reactivation}

To evaluate the activity of cholinesterase enzymes (AChE or BuChE), some methods were created. Most of these methods are based on spectrophotometry. One of these methodologies capable of evaluating the reactivation of AChE is the Ellman's method that aims to measure enzyme velocity by hydrolysis of the substrate. The reagents used with the Ellman's are dithiobisnitrobenzoic acid (DTNB) and acetylthiocholine as substrate. When acetylthiocholine is hydrolyzed, it produces thiocholine, that interacts with DTNB producing a yellow product (thionitrobenzoic acid), which concentration can be determined by UV-Visible at $412 \mathrm{~nm}$. When AChE is inhibited, there is no ability to hydrolyze acetylthiocholine without formation of thiocholine and thionitrobenzoic acid. Figure 12 shows the Ellman's test mechanism. The product concentration is determined by UV-visible, which determines the ability of the enzyme $[36,37]$.

An example of this method is the Ellman's test modified by Oliveira-Silva [38], which assesses the stability of $\mathrm{AChE}$ and $\mathrm{BChE}$ in frozen blood samples. In this type of test, first the collection of the voluntary blood sample is made, and then the collected blood is incubated with paraoxon, which is one of the most toxic OPs used as insecticides, due to the impossibility of working with chemical warfare agents, which is the rule in Brazil. Later on, there takes place separation of plasma from red blood cells by using a centrifuge, then lysis of erythrocytes using an appropriate buffer solution and the freezing of the blood for 24 hours. After these steps, the red blood cells are centrifuged for 3 times to separate the suspension of proteins called "ghost" from red blood cell membranes. The synthesized compound is added to the reactivation "ghost" which is buffered medium used for the analysis. Then, this mixture is added to the dithionitrobenzoic acid (DTNB) and the substrate acetylcholine. 30 minutes later the enzymatic activity is measured in a Ultra-violet visible (UV) spectrophotometer [38].
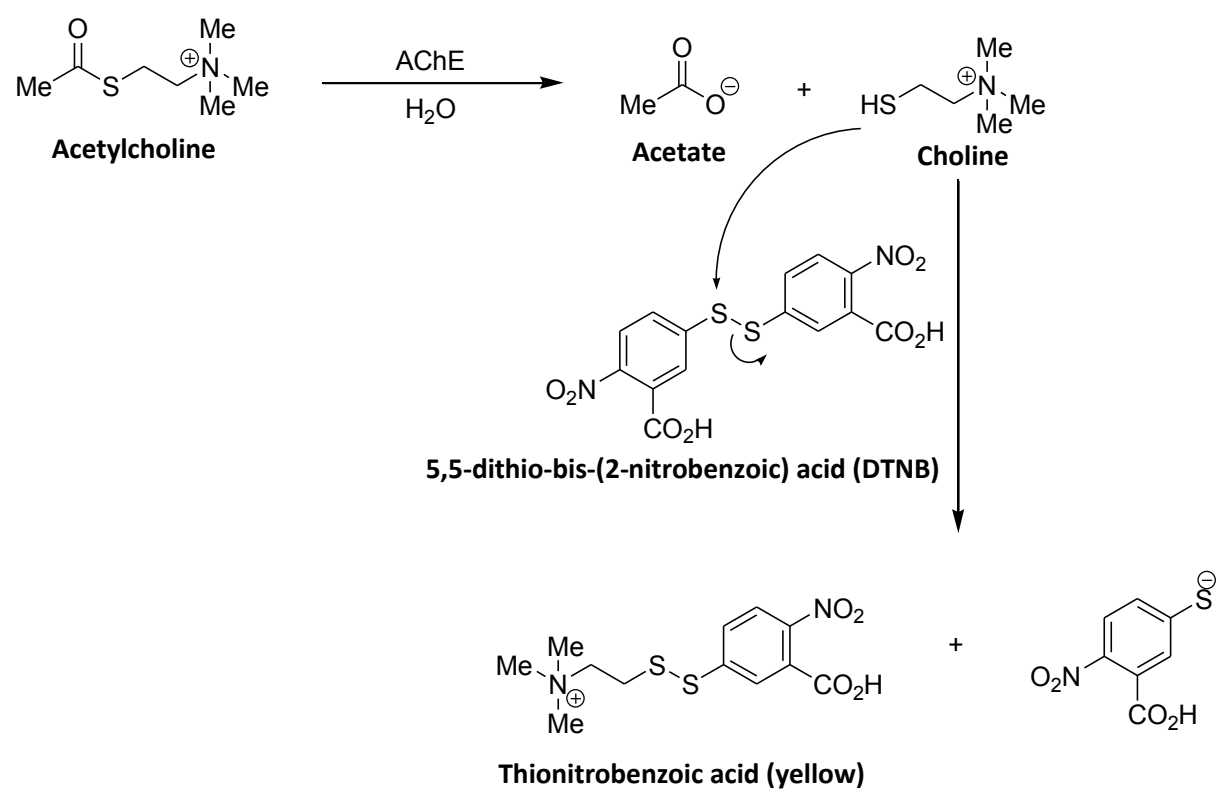

Figure 12. Scheme monitoring the hydrolysis reaction of acetylthiocholine by ultra-violet visible spectrophotometer (UV) from the Ellman's test. 
Another methodology to evaluate the reactivation of AChE is one technique by RMN [39]. This method is performed by monitoring the hydrolysis reaction of $\mathrm{ACh}$ and the formation of choline $(\mathrm{Ch})$ and acetate (Ac) in NMR tubes. If the hydrolysis occurs, the formation of the products (Ch and $\mathrm{Ac}$ ) as a function of time is observed, and also the decrease concentration of the substrate (ACh), being the concentration of all compounds is determined by integration of the selected signals. In this procedure it is necessary that the chemical shifts of the substrate and product are different, without superposition, as shown in Figure 13.

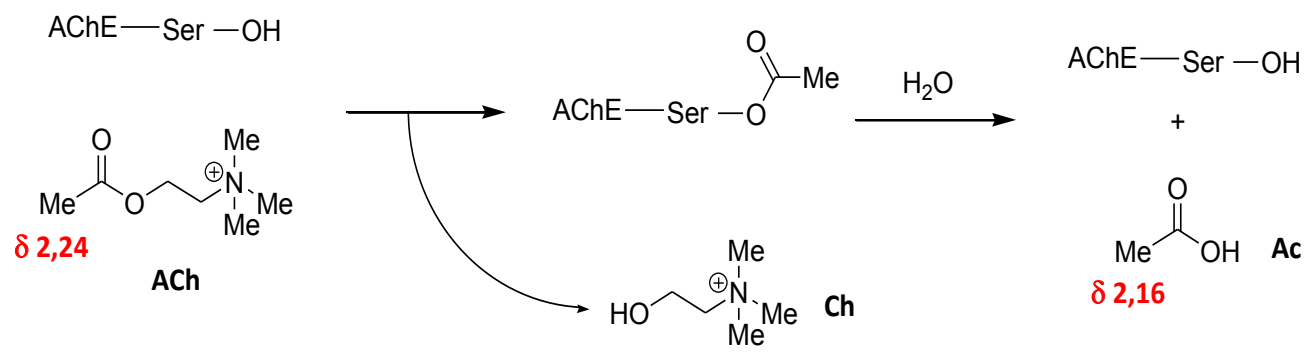

Figure 13. Hydrolysis of ACh and chemical shifts of the substrate (ACh, $2.24 \mathrm{ppm}$ ) and product (Ac, $2.16 \mathrm{ppm})$.

To accomplish this methodology, it is necessary to use a low concentration of AChE, usually $1.0 \mathrm{pM}$, because it allows the lower reaction rate, a process that permits the longer monitoring via NMR. The sample is prepared and placed immediately in the NMR spectrometer, the substrate (ACh) being the final introduced material. After introduction of $\mathrm{ACh}$ in the NMR tube the sample is introduced to the spectrometer to perform lock and shimming, and start the obtention of the ${ }^{1} \mathrm{H}$ NMR spectra. This initial process must be performed in a short time (4-5 min). All ${ }^{1} \mathrm{H}$ NMR spectra are obtained with only one scan, and each one is started after 3 to 5 minutes, in order to test the enzyme activity. These conditions are essential to permit kinetic analysis of the enzyme, and inhibition or reactivation processes. With each ${ }^{1} \mathrm{H} N \mathrm{NM}$ spectra it is possible to determine the concentration of all present compounds, a process that allows the obtention of substrate and product concentration depending of the reaction time (Figure 14) [39].

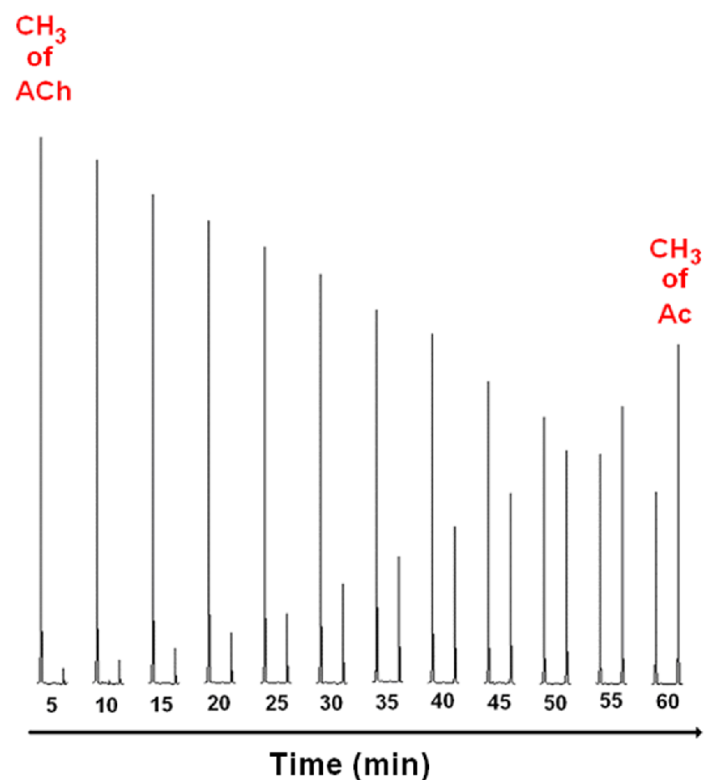

Figure 14. Sequence of spectra of the NMR scanning the methyl signal of ACh (substrate) and Ac (product) obtained in periods of 5 minutes. 
Because the NMR methodology allows very efficient determination of the structure and the chemical shift assignment of all molecules, it accurately provides the kinetic information of the enzyme without error, unlike what sometimes happens with other spectroscopic methods, such as UV-visible.

\section{CONCLUSIONS}

The key issue for defense against chemical warfare is the development of $\mathrm{AChE}$ reactivation with low toxicity agents, being able to permeate the blood-brain barrier and act efficiently against all neurotoxic OPs that inhibit this enzyme. This action would lead to appropriate conditions for defense against neurotoxic OPs agents as chemical weapons, pesticides and insecticides, being unnecessary to determine what was the used intoxicating agent.

Thus the development of scientific research is needed to plan, synthesize and evaluate new and potential agents to reactivate the phosphorylated AChE. Planned compounds must have high capacity to interact in the active site of the enzyme, and to perform nucleophilic attack on the phosphate group. One study by molecular modeling [40] has shown that other compounds, and oximes, can make reactivation, such as peroxides and hydrazones.

It is also necessary that these reactivating agents display excellent ability to interact with the active site of the enzyme, a process that can be planned for docking, dynamic and evaluated by NMR or $\mathrm{X}$-ray diffraction, which would afford the structure of the formed ligand-enzyme complexes. NMR, besides providing the structure of these complexes, also indicates their dynamics variation.

Of course, to obtain the designed complexes required efficient methods from organic synthesis, as is common in drug development processes.

It is still possible that terrorist groups and countries that are not part of CPAQ develop new chemical warfare agents, a condition that increases the importance of the study and development of new agents for protection against chemical warfare, which is a very important process for protection of the whole world population.

\section{ACKNOWLEDGMENTS}

We appreciate the economic support provided by INBEB (Instituto Nacional de Ciência e Tecnologia de Biologia Estrutural e Bioimagen), CAPES (Coordenação de Aperfeiçoamento de Pessoal de Nível Superior), FAPERJ (Fundação Carlos Chagas Filho de Amparo à Pesquisa do Estado do Rio de Janeiro), and CNPq (Conselho Nacional de Pesquisa).

\section{REFERENCES}

1. Silva, F. C.; Cardeal, Z. L.; Carvalho, C. R. Determinação de pesticidas organofosforados em água usando micro extração em fase sólida e CGAR-EM. Química Nova. 1999, 22, 197-200.

2. Silva, G. R.; Borges, I.; Figueroa-Villar, J. D.; Castro, A. T. Defesa química: histórico, classificação dos agentes de guerra e ação dos neurotóxicos. Química Nova. 2012, 35, 10, 2083 2091.

3. Domingos, J. B.; Longhinotti, E.; Machado, V. G; Nome, F. A química dos ésteres de fosfato. Química Nova. 2003, 27, 745-753.

4. Hilmas, Corey J., Smart, J. K.; Hill, B. A., "History of Chemical Warfare", Medical Aspects of Chemical Warfare, Martha K., Editor-in Chief, Borden Institute: GPO, 2008, Cap 2.

5. Macilwain, C. Study proves Iraq used nerve gas. Nature. 1993, 363, 3.

6. Morito, H.; Yanagisawa, N.; Nakajima, T.; Shimizu, M.; Hirabayashi, H.; Okudera, H.; Nohara, M.; Midorikawa, Y.; Mimura, S. Sarin poisoning in Matsumoto, Japan. Lancet. 1995, 346, 290-293.

7. Szinicz, L. History of chemical and biological warfare agents. Toxicology. 2005, 214, 167-181.

8. Okumura, T.; Takasu, N.; Ishimatsu, S.; Miyanoki, S.; Mitsuhashi, A.; Kumada, K.; Tanaka K, Hinohara, S. Report on 640 Victims of the Tokyo subway sarin attack. Annals of Emergency Medicine. 1996, 28, 129-135.

9. Holstege, C. P.; Kirk, M.; Sidell, F. R. Chemical warfare: nerve agent aoisoning. Critical Care Clinics. 1997, 13, 923-942.

10. Site of Organization for the Prohibition of Chemical Weapons. Available in: $<$ http://www.opcw.org $>$. Accessed in December 20, 2013.

11. Castro, A. T.; Figueroa-Villar, J. D. Molecular structure, conformational analysis and charge 
distribution of pralidoxime: $A b$ initio and DFT studies. International Journal of Quantum Chemistry. 2002, 89, 135-146.

12. Oliveira-Silva, J. J.; Alves, S. R.; Meyer, A.; Perez, F.; Sarcinelli, P. N.; Mattos, R. C. O. C.; Moreira, J. C. Influência de fatores socioeconômicos na contaminação por agrotóxicos, Brasil. Revista de Saúde Pública. 2001, 35, 130-135.

13. Eddleston, M.; Buckley, N. A.; Eyer, P. Management of acute organophosphorus pesticide poisoning. Dawson, A. H. Lancet. 2008, 9612, 597-607.

14. Aardewa, H.; Meerteng, J. H. J. M.; Lightemberg, J. J. M.; Peters-Polman, O. M.; Tulleken, J. E.; Zijlstra, J. G. Organophosphorus pesticide poisoning: cases and developments. Netherlands Journal of Medicine. 2008, 66, 149.

15. Site of Rede Renascença. Available in: $<$ http://rr.sapo.pt/informacao_detalhe.aspx?fid=2 6\&did $=114991>$. Accessed in December 20, 2013.

16. Site of RFI. Available in: $<$ http://www.portugues.rfi.fr/mundo/20130717morte-de-21-criancas-intoxicadas-por-merenda-e scolar-causa-indignacao-na-india $>$. Accessed in December 21, 2013.

17. Cavaliere, M. J.; Calore, E. E.; Perez, N. M.; Puga, F. R. Miotoxicidade por organofosforados. Revista de Saúde Pública. 1996, 30, 267-272.

18. Santos, V. M. R.; Donnici, C. L.; Dacosta, J. B. N.; Caixeiro, J. M. R. Compostos organofosforados pentavalentes: histórico, métodos sintéticos de preparação e aplicações como inseticidas e agentes antitumorais. Química Nova. 2007, 30, 159-170.

19. Delfino, R. T; Ribeiro, T. S; Figueroa-Villar, J. D. Organophosphorus compounds as chemical warfare agents: a review. Journal of the Brazilian Chemical Society. 2009, 20, 407-428.

20. Ordentlich, A.; Barak, D.; Sod-Moriah, G.; Kaplan, D.; Mizhari, D.; Segall, Y.; Kronman, C.; Karton, Y.; Lazar, A.; Marcus, D.; Velan, B.; Shafferman, A. Stereoselectivity toward VX Is Determined by Interactions with Residues of the Acyl Pocket as Well as of the Peripheral Anionic Site of AChE. Biochemistry. 2004, 43, 11255-11265.

21. Marrs, T.C.; Maynard, R.L.; Sidell, F.R. "Chemical Warfare Agents: Toxicology and Treatment”. John Wiley \& Sons, 1996.

22. Walker, C. H.; Hopkin, S. P.; Sibly, R. M.; Peakall, D. B. "Principles of Ecotoxicology". London: Taylor \& Francis Ltd., 1996.
23. Goodman Gilman, A. "As bases farmacológicas da Terapêutica". 10a edition, McGraw-Hill, 2005.

24. Silman, I.; Sussman, J. L. Acetylcholinesterase: 'classical' and 'non-classical' functions and pharmacology. Current Opinion in Phamacology. 2005, 5, 293.

25. Gonçalves, A. S.; França, T. C. C.; FigueroaVillar, J. D.; Pascutti, P. G. Conformational analysis of toxogonine, TMB-4 and HI-6 using PM6 and RM1 methods. Journal of the Brazilian Chemical Society. 2010, 21, 179-184.

26. Silva, G. R.; Borges, I.; Figueroa-Villar, J. D. DFT conformational studies of the HI-6 molecule. International Journal of Quantum Chemistry. 2005, 105, 260-269.

27. Petronilho, E. C.; Pinto, A. C.; Figueroa-Villar, J. D. Acetilcolinesterase: Alzheimer e guerra química. Revista Militar de Ciência e Tecnologia. 2011, 28, 3-14.

28. Musilek K.; Dolezal, M.; Gunn-Moore, F.; Kuca, K. Design, evaluation and structure-Activity relationship studies of the AChE reactivators against organophosphorus pesticides. Medicinal Research Reviews. 2011, 31, 548-575.

29. Petroianu, D. E., Lorke, D. E. Pyridinium oxime reactivators of cholinesterase inhibited by diisopropyl- fluorophosphate (DFP): Predictive value of in-vitro testing for in-vivo efficacy. MiniReviews in Medicinal Chemistry. 2008, 8, 1328-1342.

30. Kuca, K.; Musilova, L.; Palecek, J.; Cirkva, V.; Paar, M.; Musilek, K.; Hrabinova, M.; Pohanka, M.; Karasova, J. Z.; Jun, D. Bisquaternary oximes reactivation of acetylcholinesterase and butyrylcholinesterase inhibited by paraoxon. Molecules. 2009, 14, 4915-4921.

31. Kuca, K.; Jun, D.; Musilek, K. Structural requirements of acetylcholinesterase reactivators. Mini-Reviews in Medicinal Chemistry. 2006, 6, 269-277.

32. Worek, F.; Aurbek, N.; Wetherell, J.; Pearce, P.; Mann, T.; Thiermann, H. Inhibition, reactivation and aging kinetics of highly toxic organophosphorus compounds: Pig versus minipig acetylcholinesterase. Toxicology. 2008, 244, 35-41.

33. Gonçalves, A. S.; França, T. C. C.; FigueroaVillar, J. D.; Pascutti, P. G. Molecular dynamics simulations and QM/MM studies of the reactivation by 2-PAM of tabun inhibited human acethylcolinesterase. Journal of the Brazilian Chemical Society. 2011, 22, 155-165.

34. Gonçalves, A. S.; França, T. C. C., Silva, A. W. S.; Figueroa-Villar, J. D. Molecular dynamics of 
the interaction of pralidoxime and deazapralidoxime with acetylcholinesterase inhibited by the neuro-toxic agent tabun. Journal of the Brazilian Chemical Society. 2006, 17, 968-975.

35. Ribeiro, T. S.; Prates, A.; Alves, S. R.; OliveiraSilva, J. J.; Riehl, C. A. S.; Figueroa-Villar, J. D. The effect of neutral oximes on the reactivation of human acetylcholinesterase inhibited with paraoxon. Journal of the Brazilian Chemical Society. 2012, 23, 1216-1225.

36. Ellman, G. L.; Courtney, K. D.; Andres Jr., V.; Featherstone, R. M. A new and rapid colorimetric determination of acetylcholinesterase activity. Biochemical Pharmacology. 1961, 7, 88-95.

37. Castro, N. G.; Costa, R. S.; Pimentel, L. S.; Danuello, A.; Romeiro, N. C.; Viegas Jr., C.; Barreiro, E. J.; Fraga, C. A. M.; Bolzani, V. S.; Rocha, M. S. CNS-selective noncompetitive cholinesterase inhibitors derived from the natural piperidine alkaloid (-)-spectaline. European Journal of Pharmacology. 2008, 580, 339-349.
38. Oliveira-Silva, J. J.; Alves, S. R.; Inácio, A. F.; Meyer, A.; Sarcinelli, P. N.; Mattos, R. C.; Ferreira, M.; Cunha, J. C.; Moreira, J. C. Cholinesterase activities determination in frozen blood samples: an improvement to the occupational monitoring in developing countries. Human and Experimental Toxicology. 2000, 19, 173-177.

39. Soares, S. F. C. X.; Vieira, A. A.; Delfino, R. T.; Figueroa-Villar, J. D. NMR determination of Electrophorus electricus acetylcholinesterase inhibition and reactivation by neutral oximes. Bioorganic and Medicinal Chemistry. 2013, 21, 5923-5930.

40. Delfino, R. T.; Figueroa-Villar, J. D. Nucleophilic reactivation of sarin-inhibited acetylcholinesterase: A molecular modeling study. Journal of Physical Chemistry B, 2009. 113, 8402-8411. 